\title{
Communicating Inequalities: Social Disparity Phenomena in Health
}

\author{
Hadi Suprapto Arifin*, Ditha Prasanti, Ikhsan Fuady \\ Faculty of Communication Department, Universitas Padjajaran
}

\begin{abstract}
The phenomenon of HIV and AIDS has evolved into one of the most endless issues of health and social issues in the world, thereby becoming an agenda in the Suistanable Development Goals (SDG's) Indonesia until this year. Like the iceberg phenomenon, the problem of HIV AIDS is a contemporary issue related to human risk behavior, not just about health problems, but also about the social problems of one's relationship with the environment. This is what triggered the emergence of social disparity in the tourist area of Pangandaran. The latest data shows Pangandaran as one of the highest areas of HIV AIDS infections. In reality, there is still a gap or disparity between geographic regions, population groups, and socioeconomic levels. Therefore, authors want to know the efforts of local government in highlighting cases of social disparity for HIV AIDS infections in the tourist area Pangandaran. The result of the research shows that there is still a social disparity phenomenon for people living wih HIV AIDS (ODHA) in Pangandaran tourism area, mainly related to 1) Facilitation of health services; 2) HIV AIDS epidemic and; 3) Availability of trained human resources to serve ODHA in Pangandaran. In this case, the local government continues to work and coordinate with various parties, communities, including NGOs of the Matahati Foundation and AHF (AIDS Health Care Foundation) to minimize social disparities for people living with HIV AIDS (ODHA) in Pangandaran.
\end{abstract}

Keywords: Social Disparities, People Living with HIV/AIDS (ODHA), Pangandaran

\section{Introduction}

HIV AIDS is not a familiar word recently. This phenomenal health problem has not been resolved until now, one of the worrisome conditions occurred in this tourism area Pangandaran. Like the iceberg phenomenon, the issue of HIV and AIDS is a contemporary issue related to human risk behavior, not just health issues, but also the social problems of one's relationship with the health environment. This is what triggered the emergence of social disparity in the tourist area of Pangandaran. In fact, there are still gaps or differences between geographic areas, population groups, and socioeconomic levels for people with HIV AIDS. Therefore, the authors want to know the efforts of local governments in highlighting cases of social disparity against HIV AIDS patients in the tourist area Pangandaran. Therefore, the authors raise this research with the title "COMMUNICATING INEQUALITIES: SOCIAL DISPARITY PHENOMENA FOR PEOPLE LIVING WITH HIV-AIDS (ODHA)".

Based on data obtained from Pangandaran District Health Office, Madlani (2017) said that the period of January to July 2017 as many as 43 people stated positive HIV[1]. Latest data from FGD results that have been done on August 28, 2017 on the campus of Padjadjaran University Pangandaran, showed that the number of people living with HIV AIDS recorded Pangandaran Health Office, there are 4 people died until July 2017.

The real step that must be done, does not mean we have to stay away from the HIV AIDS sufferer, but need a real form that contribute in preventing and tackling HIV AIDS in Pangandaran. This is what should be a real effort to address the phenomenon of social disparity for people with HIV AIDS.

\footnotetext{
* Corresponding author: dithaprasanti@gmail.com
} 
Similar research results are also conducted by Fitrantus and Rukminingsi (2015), which examines the implementation of Local Regulation No. 4 of 2013 (Case Study at Puskesmas Putat Jaya) which is low communication between government agencies, sources are sufficient, lack of disposition, and organizational structure which deals with SOPs that are easy and affordable for all levels of society as well as participation from the private sector[3].

Beside that, Parker (2003) in their research abput HIV AIDS also said that there has been a recent resurgence of interest in HIV and AIDS-related stigma and discrimination, triggered at least in part by growing recognition that negative social responses to the epidemic remain pervasive even in seriously affected communities. Yet, rarely are existing notions of stigma and discrimination interrogated for their conceptual adequacy and their usefulness in leading to the design of effective programmes and interventions. Taking as its starting point, the classic formulation of stigma as a 'significantly discrediting' attribute, but moving beyond this to conceptualize stigma and stigmatization as intimately linked to the reproduction of social difference, this paper offers a new framework by which to understand HIV and AIDS-related stigma and its effects. It so doing, it highlights the manner in which stigma feeds upon, strengthens and reproduces existing inequalities of class, race, gender and sexuality. It highlights the limitations of individualistic modes of stigma alleviation and calls instead for new programmatic approaches in which the resistance of stigmatized individuals and communities is utilized as a resource for social change[4].

Purnomo (2015) has done the research about HIV AIDS epidemic. The HIV and AIDS epidemic is a fact that is now facing in some parts of Indonesia. The epidemic of HIV and AIDS is still dynamic and turbulence so the path of its spread is still unpredictable. HIV / AIDS is an extreme problem that is easily migratory so geographically and socially unsteady to date, ease of movement or change direction is a global picture of this HIV / AIDS epidemic. Since the discovery until now the AIDS is virtually spread across the country. Therefore, a strategy is needed from various parties to reduce and overcome the spread of this deadly virus[5].

The results of previous research conducted by Purnomo, D (2015) describes the policy analysis in the prevention and control of HIV AIDS in Kab.Malang. This research shows that HIV and AIDS prevention policies in Malang Regency have been implemented in accordance with the objectives of the policy making which is stated in the Regional Regulation[5].

\section{Methodology}

The research approach is qualitative approach with action research method. Data collection techniques in action research research uses several data collection techniques[6].

1. In-depth Interview

2. Participant Observation

3. Focus Group Discussion (FGD)

4. Study of literature.

A reference study of various library materials was done to obtain various secondary data about people living with HIV AIDS (ODHA) numbers in Kab.Pangandaran. Both of them about data collection techniques were very important in this research.

At the end, the most important feature of action research is that it is an attempt to solve problems, while seeking scientific support ${ }^{2}$.

\section{Discussion}

Based on observations, in-depth interviews, and documentary studies that have been done, the authors can illustrate some of the steps related to Pangandaran related to social disparity for people with HIV AIDS.

One of the informants, people living with HIVAIDS (ODHA), SN, the mother who had a child, told her what happened:

"Hmm yes, yes ... I ... I'm really sad
because if people know I'm HIV
positive, I will dijauhin and ostracized.
I also do not know what to do. I feel
safe right now because people do not
know, except my close family. If the big
family also I do not want to tell tau. In
fact, my brother who knows also
ngejauhin me because HIV is
contagious he said. So I also choose not
want people or neighbors know about
the disease I suffered. "
(The Result of Interview on Sept $29^{\text {th }}$,
2017)

Chairman of the Foundation Matahati, Ag, also explained as follows:

Yeah, that's true, we can not close the ears if it is out there, especially in Pangandaran, people still see HIV AIDS is a disease that should be shunned until the HIV positive person also must be shunned. Precisely that is wrong, should be embraced and motivated to have the spirit of life. This is what we do, we also work with the government so that they also get the best health service. We come to various departments, start the health service, social service, district government, to the puskesmas also yes to establish cooperation, especially for access to health services, including health 
facilities that support also make this ODHA yes. So, in fact the government is now again trying to improve facilities, with the development of hospitals in Pangandaran, continue from the epidemic, and the availability of human resources at the Health Center-Puskesmas. "

(The Result of Interview on Sept $28^{\text {th }}$, 2017)

The statement was also confirmed by the Health Department, YAM said that social disparities that occur for people with HIV AIDS in Pangandaran has also been attempted to overcome.

"Yeah, we are also thinking about
efforts to overcome the gap or social
disparity that may not be realized by the
community. We also coordinate with
various related agencies, same Pemkab
also, if from health office itself, we've
done some steps, namely: the provision
of health care access yes, we are trying
to arrange the establishment of
hospitals in Pangandaran, continue in
terms of human resources as well, we
continue train the human resources who
handle this particular PLWHA, we
continue to spread these human
resources to 4 puskesmas; where the
clinic is available to the laboratory for
the examination of his HIV test, the
Parigi Puskesmas, Cikembulan Public
Health Center, Pangandaran
Community Health Center and Cimerak
Community Health Center. "
(The result of interview on Sept 29,
2017)

The above statement also describes the efforts made by local government in reducing the phenomenon of social disparity for people living with HIV who are still afraid to be ostracized by society. The phenomenon of social disparity seen in the reality of people who look at people living with HIV as carriers of the virus that is contagious and deadly.

Whereas the transmission of the virus is through sexual contact, injection of needles contaminated with HIV, blood transfusions or HIV-contaminated blood components, pregnant mothers to their infants and HIV-infected sperm stored in sperm banks, which means sexual intercourse is a type of sex (malefemale), homosexual (male), or bisexual relationships, sometimes having sex with men and sometimes also with women ${ }^{7}$.

In other cases, the government has also made the issue of HIV AIDS as one of Suistanable Development's Goals (SDGs) until 2017. This never- ending health problem is the fact of the development of an epidemic caused by HIV / AIDS.

The HIV and AIDS epidemic is a fact that is now facing in some parts of Indonesia. The epidemic of HIV and AIDS is still dynamic and turbulence so the path of its spread is still unpredictable. HIV / AIDS is an extreme problem that is easily migratory so geographically and socially unsteady to date, ease of movement or change direction is a global picture of this HIV / AIDS epidemic. Since the discovery until now the AIDS is virtually spread across the country. Therefore, a strategy is needed from various parties to reduce and overcome the spread of this deadly virus ${ }^{5}$.

The HIV AIDS epidemic also occurs in the tourist area of Pangandaran. This point is also what the local government is doing with other related agencies to reduce the phenomenon of social disparity for people living with HIV. Yayasan Matahati also cooperates with cadres distributed to all villages in Pangandaran to conduct HIV AIDS education, one of the messages conveyed through the socialization is so that people do not stay away and ostracize people living with HIV, but it should give the spirit of life so as not to despair.

This social disparity phenomenon also leads to stigmatization actions that cause people with HIV are not ready if the illness is suffered yanh this publicly known. People living with HIV also experience various problems, for example to get a job, traveling, chatting with their family, or even to socialize with the surrounding community. Health information awareness program on HIV AIDS to the community is one of the most important things to do to remove stigma as a result of social disparity felt by people living with HIV AIDS (ODHA) in Pangandaran. This has been done by Matahati Foundation by forming and training cadre teams and in collaboration with health centers and related health offices to conduct counseling and examination of HIV AIDS test in villages spread in Pangandaran area.

Based on the above description, the authors obtained the findings in the field which shows that the efforts made by local government to reduce the phenomenon of social disparity for people living with HIV AIDS (ODHA) in Pangandaran tourism area, mainly related to:

1) Facilitation of health services,

2) HIV AIDS epidemic, and

3) Availability of trained human resources to serve people living with HIV AIDS (ODHA) in Pangandaran

In this case, the local government continues to work and coordinate with various parties, communities, including NGOs of the Matahati Foundation and AHF (AIDS Health Care Foundation) to minimize social disparities for people living with HIV AIDS (ODHA) in Pangandaran. 


\section{Conclusion}

In this study, the authors obtained the reality that there is still a phenomenon of social disparity for PLWHA in Pangandaran. There are fears and concerns experienced by people living with HIV if people know the disease suffered, so some people living with HIV also choose to hide this disease to neighbors and the surrounding environment, even including large families. The phenomenon of social disparity is a form of inequality for PLHIV that needs to be addressed immediately. Therefore, the authors also found some conclusions about the efforts of local governments in reducing the phenomenon of social disparity for people living with HIV in the tourist area of Pangandaran, as follows:

1. Facilitation of access to health services, this is indicated by the efforts of Dinas Kesehatan in improving HIV AIDS service center and examination that has been spread in four puskesmas in Pangandaran, namely Parigi Health Center, Pangandaran Health Center, Cikembulan Health Center, and Cimerak Health Center.

2. Efforts to minimize the HIV epidemic level that is still unpredictable, because it is like the iceberg phenomenon of the HIV AIDS epidemic. This was overcome by the cooperation of Yayasan Matahati with the Health Office as well as forming a cadre team to conduct HIV AIDS prevention information counseling with one of the messages conveyed so as not to isolate the people living with HIV AIDS (ODHA) encountered in the neighborhood.

3. Upgrading and training of Human Resources, in this case the training of health workers capable of serving people living with HIV AIDS (ODHA), which is spread in four puskesmas earlier, as evidence of efforts to reduce the phenomenon of social disparity perceived people living with HIV AIDS (ODHA) in terms of health services. improvement of human resources needs to be a focus in order to create a health environment and be a support system that can accept HIV / AIDS sufferers.

\section{References}

1. Madlani, Retrieved Aug 26, 2017 from http://www.harapanrakyat.com/2017/07/dinkespangandaran-harapkan-perda-pencegahan-danpenanggulangan-hivaids (2017).

2. A. Suharsimi, Prosedur Penelitian: Suatu Pendekatan Praktek, (2006).

3. Y. Fritantus and N. Rukminingsih, Implementasi Kebijakan Penanggulangan Hiv Dan Aids Di Kota Surabaya (Kajian Peraturan Daerah Kota Surabaya Nomor 4 Tahun 2013, Studi Kasus di Puskesmas Putat Jaya, Kota Surabaya), JPAP: Jurnal Penelitian Administrasi Publik, 1(01) (2015).

4. R. Parker, \& P. Aggleton, HIV and AIDS-Related Stigma and Discrimination: A Conceptual Framework and Implications for Action, Social science \& medicine, 57(1), 13-24 (2003).

5. D. Purnomo, Analisis Kebijakan Penanggulangan HIV dan AIDS di Kabupaten Malang (Studi Pelaksanaan Peraturan Daerah Nomor 14 Tahun 2008 Kabupaten Malang), Jurnal Administrasi Publik, 3(1), 42-48 (2015).

6. V. Koshy, Action Research for Improving Practice, Paul Chapman Publishing, London (2005).

7. Z. Djoerban, Membidik AIDS Ikhtiar Memahami HIV dan ODHA, (2001). 